\title{
Elastic Worlds
}

\section{Mundos elásticos}

\author{
Robert Pratten \\ Founder and CEO at Conducttr \\ www.conducttr.com \\ (Reino Unido)
}

\begin{abstract}
- Guest paper -
This is an invited contribution and has not gone through peer review. Highlights of this article were first published on the Conducttr blog http://www.tstoryteller.com/elastic_ worlds as a teaser and hence the article here is the primary source of the ideas.
\end{abstract}

Reception date: 7 December 2018

Published: 1 January 2019

To cite this article: Pratten , R. (2019). Elastic Worlds, Icono 14, 17 (1), 5-14. doi:

10.7195/ri14.v17i1.1302 


\section{Abstract}

In participatory transmedia experiences a wide range of player agency is desirable but can be problematic if the game and storyworld boundaries are unknown or ignored. Players breaking the world boundaries can mean an experience must be aborted or stops being fun. Yet breaking the rules is fun and in learning \& development experiences like wargaming it might even be part of the goal. How then can authors of participatory experiences that play out in the real world allow players to break the rules but not break the world? How can we design an experience for the greatest player agency and the broadest scope of emergent stories yet prevent the world from travelling so far from the author's intended state that it becomes unrecognisable, unplayable or unsuitable? This paper introduces the concept of an elastic storyworld as an alternative to a persistent storyworld: a world that stretches to accommodate unexpected player actions and yet restores itself over time. Drawing on definitions of elasticity from physics, the paper suggests ways in which authors might classify and detect player-enacted distortions and how participatory experiences might be designed to be more resilient to the stresses and strains of player agency.

Key Words: Transmedia; Storyworlds; Participation; Alternate reality games; Pervasive games; Elastic worlds

\section{Resumen}

En las experiencias de transmedia participativa, es deseable una amplia gama de agencias de jugadores, pero puede ser problemático si se desconocen o se ignoran los límites del juego y del mundo de la historia. Los jugadores que rompen las fronteras del mundo pueden significar que una experiencia debe ser abortada o deja de ser divertida. Sin embargo, romper las reglas es divertido y en experiencias de aprendizaje y desarrollo como wargaming, incluso podría ser parte de la meta. Entonces, ¿cómo pueden los autores de experiencias participativas que se desarrollan en el mundo real permitir a los jugadores romper las reglas pero no romper el mundo? ¿Cómo podemos diseñar una experiencia para la mejor agencia de jugadores y el alcance más amplio de historias emergentes y evitar que el mundo viaje tan lejos 
del estado previsto por el autor de que se convierta en irreconocible, no jugable o inadecuado? Este artículo presenta el concepto de un mundo de la historia elástico como una alternativa a un mundo de la historia persistente: un mundo que se extiende para adaptarse a las acciones inesperadas de los jugadores $y$, sin embargo, se restaura con el tiempo. Sobre la base de las definiciones de elasticidad de la fisica, el artículo sugiere formas en las que los autores podrían clasificar y detectar distorsiones implementadas por los jugadores y cómo las experiencias participativas podrían diseñarse para ser más resistentes a las tensiones y tensiones de la agencia de jugadores.

Palabras clave: Transmedia; Participación; Juegos de realidad alternativa; Mundos elásticos; Juegos omnipresentes; Storyworlds

\section{Introducción}

Persistent storyworlds are simulations of fictional realities that evolve over time: they change shape as players interact and leave their marks on the world. Persistence is usually considered to be a good thing for a world: it feels more like the real world where time is perceived to move only in one direction and where conflict and consequences shape the future.

The problem with persistence comes when the storyworld evolves in an undesirable way. Undesirable might mean that stories in the world are no longer consistent with each other or in the case of a live experience that players stop having fun or in a learning experience that the training goals won't be met.

It's usual to try to prevent this by constraining player agency so that it's not possible to do undesirable things that would distort the world or to use game mechanics that erode the changes - for example finding ways for players to spend or loose their money so as not to build up too much wealth or having weapons break and become damaged with use. This ebb and flow is the conservation of the world economy and in wholly digital games this can designed to work satisfactorily. 
In real-world participatory transmedia experiences, however, the players have more agency and the author cannot control all the variables. Player actions can be wide ranging and unexpected.

\section{Transmedia Worlds}

The diagram below represents a story inside a transmedia storyworld.

If players play by the rules of the world it shouldn't be possible to break through the walls of the storyworld because to do so would violate the world's order.

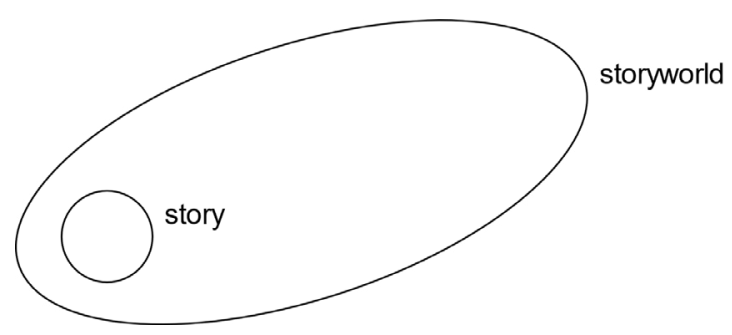

Figura 1

In a transmedia franchise, a story that exists outside the world might be called "out of canon". Works that are out of canon tend to contain much of the DNA of the original storyworld but they live outside of it, perhaps in a new parallel world or metaverse of worlds. In a transmedia franchise, it's easy to jump between worlds because each world exists in a different physical or digital representation. In the case of a physical book it's possible to hold a different world in each hand and understand that the two can live together: the fan's lived experience is one that moves from world to world - from canon to out-of-canon (or perhaps between canons in the case of a rebooted franchise).

In a participatory transmedia experience however, for example an alternate reality game, the player's experience of the fictional reality can only be in the here and now. This means that an emergent story created by the player's action or inaction, if allowed to do so, can break the world rules and hence potentially create 
an undesirable new world order.

Breaking the world rules becomes increasingly more likely the more agency players are given.

the natural world order

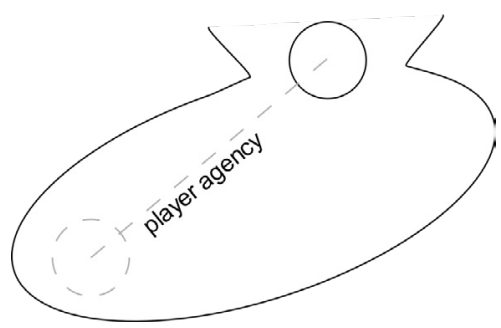

Figura 2

What if, rather than have the world break, it was elastic enough to allow a temporary distortion. This means that the player action is considered in-world but we introduce a process to restore the world over time.

The figure below shows a distorted storyworld curved out of shape by the emergent player story. Rather than break the storyworld, the player innovation has been accommodated and now the world is a different place.

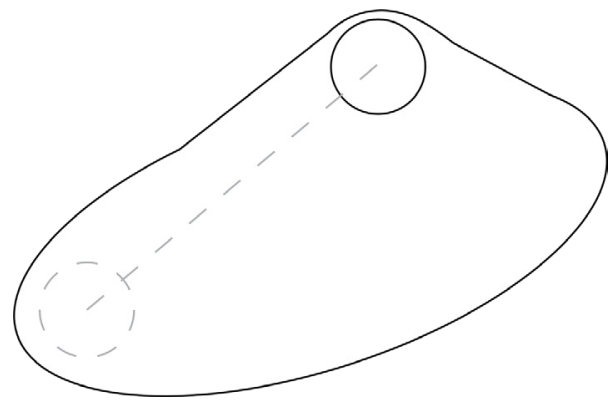

Figura 3

An example of this might be a medieval game in which the blue team must defend a castle and the red team must attack it. The world creator (author) has given the players horses, swords, catapults, battering rams, drawbridges, moats and boiling oil. Yet blue decides that "we get visited by aliens and get given a ray gun". The ray gun appears to break the rules but is this innovation exactly the type of creativity/out- 
of-the-box thinking the experience was intended to create? In an elastic world, the innovation would be allowed to stretch the storyworld boundaries.

Stretching and bending to allow the player's contribution doesn't mean that we must live with it forever. The misshapen storyworld might not be desirable for many reasons and so we need a way to restore the original world in a controlled way. A storyworld that restores itself to an inherent "natural order" could be called an elastic storyworld.

In the illustration below the elastic world contracts and moves the player story back inside the acceptable storyworld boundary and restores the original world order. An elastic world might have an elastic modulus that defines how quickly or slowly the "true" world order is restored: very elastic worlds snap back quickly while inelastic worlds look more like persistent worlds with only a creeping return to the desired world order.
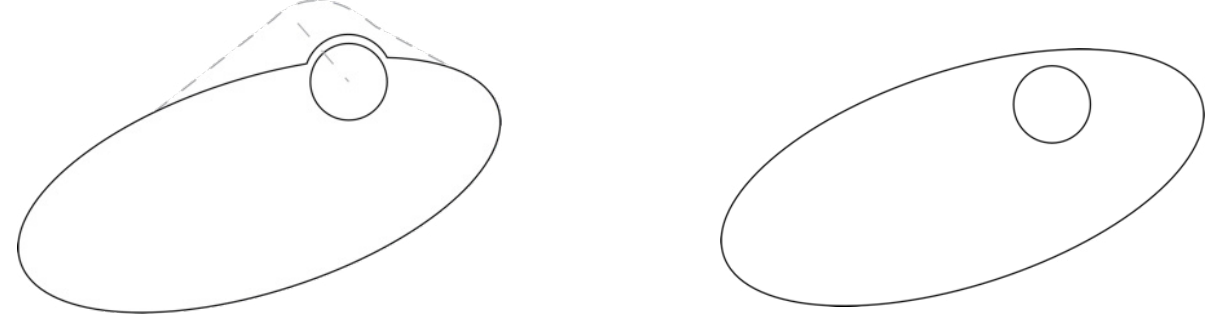

Figura 4

\section{Measuring distortion}

Using the definition of elasticity used by physics we could say that:

Stress = how much of the world is impacted

Strain = how far it has moved from the recognisable desired world

To use these concepts in practice, we first need to dimension the world so we can recognize where the distortion is happening. One approach would be to look at the underlying world in terms of its mythos, typos etc and perhaps use a system 
like PESTEL (Political, Economic, Sociological, Technological, Legal, and Environmental) which would provide six dimensions for the world. However, it might not be necessary or desirable to use a very low-level or detailed approach because all we really need to manage is the player's experience of the world.

What if, then, we limit the measurement of distortion to the touchpoints of the world. In my active story system approach (http://activestorysystem.com), these audience touchpoints could be limited to:

- Characters

- Factions

- Objects

- Locations

Character distortion might be taken to mean a change of the character's world view (such as character turns from "goodie" to "baddie") or gets killed or disfigured or a new character is introduced. A stress introduced into factions might mean that rivalries are put aside or collaborations stopped. In short, any disruption to the author's original world design which disturbs the original intentions is a stress to the system.

World distortion could potentially be limited to four types of stress:

- Addition

- Removal

- Move (e.g. geographic location)

- Attribute change (e.g. good to bad, broken to working)

This would give a $4 \times 4$ matrix of touchpoints and stresses to describe and measure how much a storyworld was distorted from its original design and operation. I shall return to this in the next section. 
With reference again to the physics definition of elasticity, the "strain" on the world can be understood to mean size or impact of the disturbance. For example, if players kill a central character then that's a greater strain than the death of a minor character; players injuring a character is less of a strain than them killing it. Hence for each of the stresses there will be strains. Stress divided by strain is the measure of how ductile a material is and here for a participatory storyworld it would mean how resilient the world is to player actions - that is, how accommodating it is to player distortion without breaking down and causing the experience to no longer make sense or lose its way.

\section{Restoring the world}

The table below shows possible actions to restore the world given the four dimensions and the four stresses. For example, if players add a character, it can be killed; if players remove a faction, it can re-emerge via the emergence of a new character; if an object is moved it can be moved back and if a location is changed it can be changed back.

\begin{tabular}{|c|c|c|c|c|}
\hline \multicolumn{5}{|c|}{ Stresses } \\
\hline Dimensions & Added & Removed & Moved & Changed \\
\hline Characters & Killed & $\begin{array}{l}\text { Promotion of a new } \\
\text { character }\end{array}$ & Moved back & $\begin{array}{l}\text { Change of heart, repaired, } \\
\text { rebuilt }\end{array}$ \\
\hline Factions & Disbanded & $\begin{array}{l}\text { Emergence of new } \\
\text { character to rebuild } \\
\text { the faction }\end{array}$ & Moved back & $\begin{array}{l}\text { Change of heart, rebuilt or } \\
\text { scaled down }\end{array}$ \\
\hline Objects & $\begin{array}{l}\text { Broken or } \\
\text { stolen }\end{array}$ & $\begin{array}{l}\text { Object found (if } \\
\text { stolen, returned or } \\
\text { rescued }\end{array}$ & Moved back & Broken and restored \\
\hline Locations & $\begin{array}{l}\text { Abandoned, } \\
\text { disbanded, } \\
\text { destroyed }\end{array}$ & Rebuilt & Moved back & $\begin{array}{l}\text { Returned to former state via } \\
\text { human forces (hacking, des- } \\
\text { truction, rebuilding) or forces } \\
\text { of nature (wind, rain etc.) }\end{array}$ \\
\hline
\end{tabular}

\section{Tabla 1}

The speed with which a player distortion can be reversed is a measure of its elasticity and also a sign of its resilience. Some storyworlds may lend themselves to restoration more than others. For example, a fantasy world that accommodates 
magic can potentially allow for any new spell or potion invented by a player to have an exact opposite invented by the author. A resilient design will allow an easy explanation for how the reversing action came about so quickly.

A trickier distortion to deal with might be the death of the protagonist. Killing a central figure could likely have a ripple effect across the other dimensions but authors should be ready for this if it is to be allowed. In restoring the world, we must either find a new protagonist who will continue the fight or restore the dead character to life. Again, the nature of the world will provide the most appropriate solution. In a futuristic world the protagonist could be brought back with technology, in a magical world with spells. If the story is set in contemporary times, then explanations might be that either the character didn't really die (e.g. Lincoln in Mafia III comes back to life despite seemingly being shot in the head!) or if the character really is dead then a successor steps up to take its place.

Of course replacing the protagonist (rather than rehabilitating it) feels like a persistent world rather than an elastic world but it depends on the author's intentions for the story and for the players. In an educational or training experience, for example, it might not matter that one character is replaced for another so long as its needs and wants are the same.

\section{Resilience}

If elasticity is the measure of the worlds ability to return to a desired state, then resilience is the measure of its ability not to break. It's like stretching an elastic band until it snaps: how much strain can the world take before it can't return to the desired world?

In designing a participatory storyworld, maybe it's possible to perform a risk analysis of which dimensions and stresses are the world's greatest weakness. This will likely be where the storyworld has the greatest dependence such as, say, the rings in Lord of the Rings. Then, having identified the weaknesses, the author can devise ways to counter the stress. 


\section{Conclusions}

There is usually a need to maintain the "normal" world order in a participatory experience to ensure as many people as possible have a nice time or because it's important for achieving certain training goals. However, transmedia experiences that play out in the real world grant players a good deal more agency that can be controlled by purely digital experiences. This can result in players ignoring or wilfully testing the world boundaries which can be fun to those players but can be to the detriment of others or to achieving the learning goals.

Rather than attempt to completely constrain player actions, the idea of an elastic storyworld is one in which player distortions momentarily bend the world but do not break it. Indeed, rather than breaking through the storyworld boundaries and their actions ruled either inadmissible or out-of-canon, the storyworld momentarily accepts their challenge but over time reverts back to the author's desired world order.

Future work in this area could look for examples of elastic worlds, refinements and alternatives to the approach suggested here and how detection and restoration could be automated by real-world gaming engines.

\section{(c) $\underset{\mathrm{EY}}{(\mathrm{i})}$ (9)}

Esta obra está bajo una licencia de Creative Commons Reconocimiento-NoComercial 4.0 Internacional. 